\title{
Digital solutions for healthy eating
}

\author{
Marina A. Nikitina ${ }^{1}$, Irina M. Chernukha ${ }^{1^{*}}$, Andrej B. Lisitsyn
}

A b s tra c t: This study presents a computer system used for assessment of a healthy diet. Based on mathematical models, the system provides a solution for the problem of structural-parametric diet optimization, adjusted for a variety of constraints and conditions, and produces the optimal solution for the given utility functions. The information basis of the system is a database containing nine independent tables. Each table contains 15 fields. The structured query language (SQL) is used. An aggregate algorithm for implementing the solution of healthy diet composition, containing four stages, with due consideration for a "human health passport" is described. At the first stage, based on anthropometric data and biomarkers (hemogram, acidity of gastrointestinal tract) of a person's physiological state, the system generates a user model ("a human health passport"). The model considers the risk of disease and the gastrointestinal tract status. At the second stage, the system allows a choice of food products to be made, based upon the physiological state of a person and that proactively excludes undesirable food products, dishes, and culinary products. At the third stage, the developed diet is assessed, and the food nutrients (proteins, fats, carbohydrates, vitamins, macro- and microelements) in the diet are analyzed and compared with the recommended norms for this particular person. At the fourth stage, the adequacy of the diet is assessed according to the quality function.

Keywords: computer system, health, diet.

\section{Introduction}

According to the World Health Organization (WHO, https://www.who.int/ru), a number of diseases are associated with an insufficiency or excess of certain components in the daily human diet (Figure 1). In Western Europe, $77 \%$ of all diseases are non-communicable diseases, while in $86 \%$ of cases they are the cause of death. The same trend is observed in Russia.

Medical data indicate interrelation between nutrition and the most common noncommunicable diseases. Many cardiovascular diseases, different cancers, diabetes, gout, and obesity are directly linked with excess intake of calories due to fats, simple carbohydrates, table salt, diets with reduced content of vitamins and dietary fibers (Bush et al. 2020).

Maintaining and strengthening human health is impossible without adequate nutrition. Constant violation of dietary regime inevitably leads to pathological changes in vital functions. This is due to the deep impact of nutrition on all biochemical and physiological processes of the body. It is this fundamental influence that underlies the use of diet therapy - therapeutic, functional nutrition - for smoothing, treating and reducing the risk of various diseases. When recommending a particular diet, a dietitian should use not only biochemistry data (protein, carbohydrate, and lipid statuses, immune parameters, and biochemical blood analysis), physiology data (weight deficit, activity factors, and injuries), and food hygiene data (volume, weight, consistency, and temperature of food), but also take into account individual parameters (age, anthropometric, and caliper measure data). The mathematical apparatus is widely used in the analysis of nutrition problems (Sukhatme, 1961; Edwardson, 1974; Anderson and Earle, 1983; Alpaslan, 1996; Kaldirm and Köse, 2006; Lv, 2009; Sahingoz and Sanlier, 2011) as well as principles of food combinatorics when designing combined food products (Lipatov, 1985; Ivashkin et al, 2000; Nikitina et al, 2019; Youbo, 2009).

Designing an individual balanced diet considering many factors (individual intolerance to some components, anthropometric indicators, body mass index, indicators of nutritional and biological value) is impossible without the use of a mathematical tool and modern digital techniques.

The article (Chen et. al, 2018) summarizes scientific and practical prerequisites for creating

${ }^{*}$ Paper was announced on $61^{\text {st }}$ International meat industry conference - meatcon 2021 held on Zlatibor mountain on September $26-29^{\text {th }} 2021$.

${ }^{1}$ V.M. Gorbatov Federal Research Center for Food Systems of RAS, Moscow, 26, str. Talalikhina 109316, Russia.

*Corresponding author: Irina Chernukha, imcher@inbox.ru 


\section{Medical Complications of Obesity}

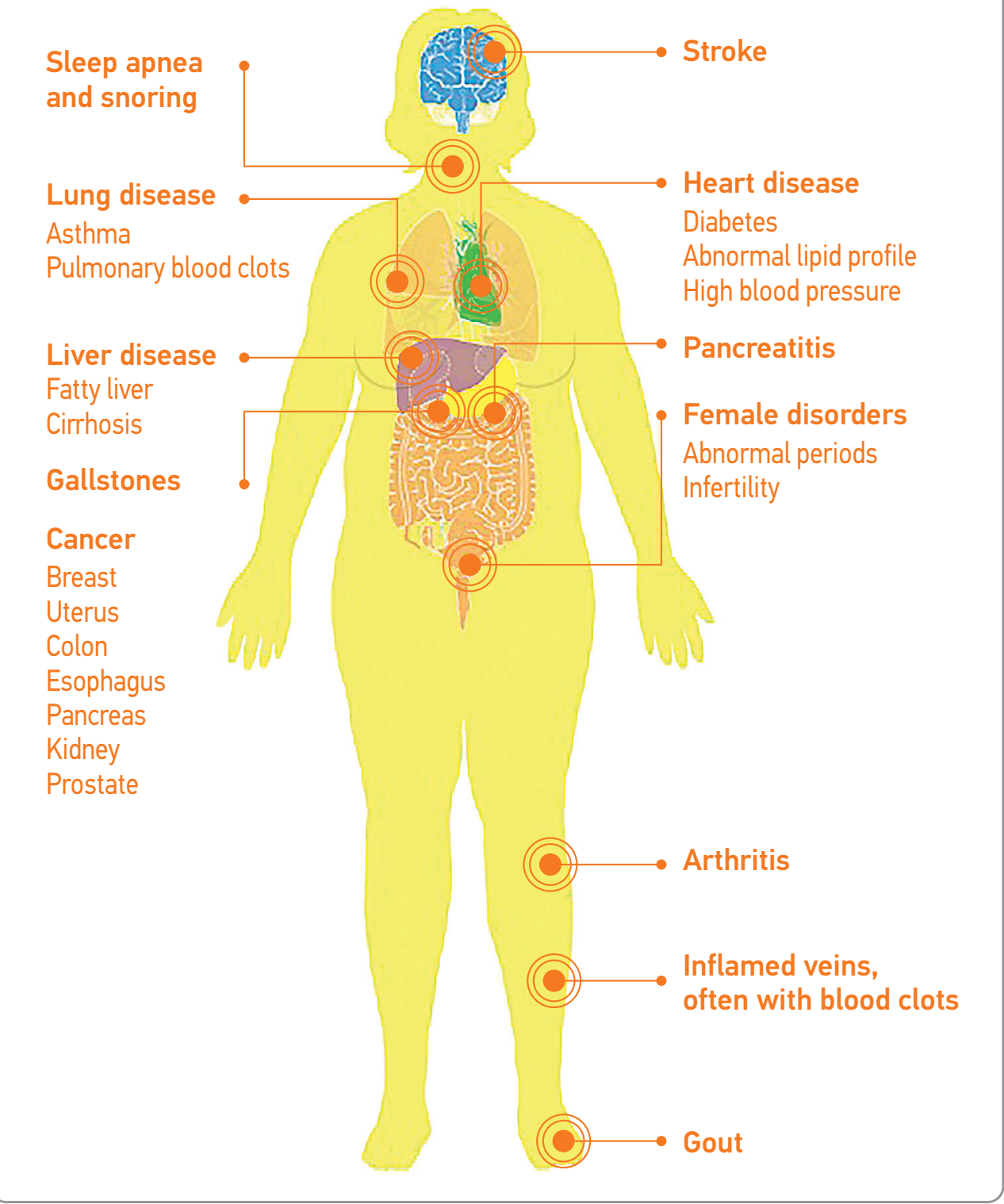

Figure 1. Medical complications of obesity

(https://www.cdc.gov/vitalsigns/adultobesity/infographic.html)

multicomponent foods with desirable quality characteristics and consumer properties. The Russian methodology of food design originated from Lipatov (1985). His six basic principles of designing balanced multicomponent foods are still relevant today. At the next stage, Ivashkin (2000) improved formulations using the methods of system analysis, modeling, and product range optimization. Modern food chemistry, food biotechnology, and information technologies allow for effective computer design and optimization of multicomponent food formulations for specific population groups. Authors (Lisitsyn et. al 2020; Musina and Lisin, 2015; Musina et. al, 2017) proposed a methodology for system modeling of multicomponent food products. They defined system modeling as a strategy for studying and creating biosystems, particularly food products, their formulations, and production technologies.

An approximate model for selecting a personalized diet is proposed in. The author views personalized nutrition as individually adapted nutrition. With this approach, the gender, age, level of physical activity, presence of different chronic diseases and personal food preferences are taken into account. Individually tailored nutrition is aimed at prevention and treatment of different diseases, reduction of the 
negative effects of harmful environmental factors, and support of healthy lifestyle. It is impossible to choose a diet without relying on achievements of modern genetics and nutrition science.

To address the issue of adequate nutrition that meets the needs and capabilities of the human body and is balanced by all indicators of nutritional and biological value, it is necessary to process large amounts of data. First of all, Big Data (big arrays of information and knowledge about the subject area) is used (Davis-Dusenbery, 2017; Wu et. al, 2017). Our Big Data should contain information about dietary menus, functional and specialized products, nutritional characteristics of differentiated groups of people (students, pregnant women, retirees, etc.), norms of food nutrient consumption as per the region of residence, climatic zones, gender factors, anthropometric indicators (age, weight, body mass index), general and specific medical and biological requirements, characteristics of food consumption (whether there is an allergy or not), as well as information about the source of immune status disorders. It is also necessary to consider the combinability of foods in one diet, and various effects of the combination, such as synergy and antagonism.

In this regard, the issue of therapeutic, functional food can be solved by using a knowledge-oriented system of adequate nutrition, which will help the doctor to quickly and correctly design (select) an adequate diet, taking into account the state of nutrition, individual characteristics, and external factors.

The aim of this work is to develop a methodology and a computer system for assessing the quality of dietary structures for differentiated groups of population, as well as a specific person.

\section{Information techniques for optimizing adequate personalized human nutrition}

The development of a knowledge-oriented system involves building a knowledge base that contains basic concepts and relations between them. In the case under consideration:

- region of residence;

- activity factor;

- injury factor (operations, bone fractures, traumatic brain injuries, etc.);

- current state of nutrition;

- anthropometric data;

- caliper measure indicators;

- indicators of trophological status;

- indicators of micro- and macronutrient status;

- indicators of vitamin status;
- database on the chemical composition of food products;

- database of biomedical nutritional requirements depending on the disease.

For example, the intake of vitamin B1 influences carbohydrate metabolism, heart and lung functions; vitamin B6 content - metabolism of amino acids and fatty acids, nervous system functions; folic acid (folate) - maturation of red blood cells, DNA and RNA synthesis; calcium - blood clotting, nervous and muscular system functions, heart functions; phosphorus - muscle and nervous system functions; magnesium - energy production, acid-base balance, etc. (The Merck Manual of Medical Information Whitehouse Station, 2008).

These data in the knowledge base can be presented as structural and parametric matrices of relations that include three main blocks: patient's physiological state, diet indicators, environmental factors, and many relations within blocks and between blocks and groups of factors.

Each individual block has its own parameters and attributes, for example, the block Patient's physiological state includes age, gender, anthropometric indicators - body weight, height, body mass index, shoulder circumference; caliper measure indicators - fat content, thickness of the fold 2 centimeters above the navel; thickness of the fold over the biceps, etc. Nationality and religious traditions are important. Expert estimates, correlation, and simple and multiple regression coefficients influence estimates found as a result of active experiments, while possible functions, relations, and conversion algorithms can be used as formalized characteristics of relations between parameters of structural and parametric characteristics.

General diagnostics of the person's condition and decision-making in the knowledge-oriented system of adequate nutrition is carried out using the following algorithm. In the first stage, 69 physiological indicators of the patient (trophological status indicators, macroand micronutrient composition) and 5 indicators of external factors (region of residence, religion, nationality, activity, injuries) are entered. In the second stage, the prognostic risk index, main energy exchange and actual energy expenditure are calculated in order to further determine the person's (patient's) needs for proteins, fats, carbohydrates, etc. The main diagnostic procedure is then further conducted. It forms a structural and parametric situational model of the abnormal human condition being measured and searches for deviations from normal values (normative indicators from the Institute of Nutrition, FAO/WHO, etc.). 


\subsection{Identification algorithm}

The main mechanism of the diagnostic procedure is a cyclic process of moving the matrix of structural and parametric characteristics along the diagonal (non-diagonal elements reflect relations between the patient's state indicators) with a comparison of values of diagonal elements with the norm levels. If an indicator does not match the reference value, values of the indicators with which it is associated are tracked. Upon the occurrence of a loop (i.e. repeated repetition in the cycle of the same indicator) all links of this diagonal element are artificially broken, while the above-mentioned procedure is repeated until the next indicator. All abnormal values of indicators are stored in an array of deviations from the norm. Based on its interaction with the knowledge base, the system user is provided with the conclusion of the diagnostic procedure.

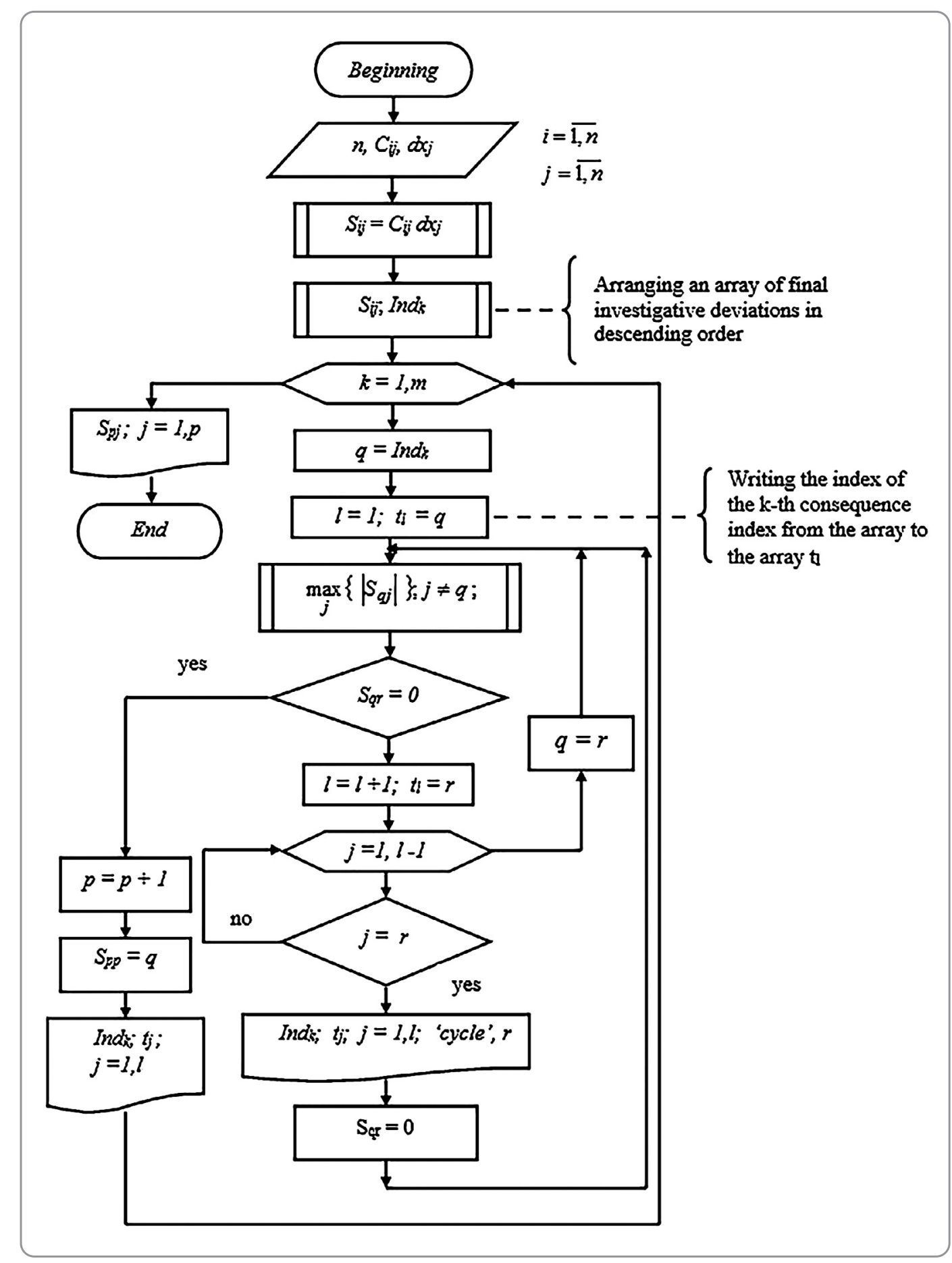

Figure 2. Block diagram of the algorithm for diagnosing the abnormal state of a nutrition system 
The identification algorithm contains (Figure 2) a block of the situation matrix formed and the procedure for finding the causes of the anomalous state of the system.

The procedure is a cycle of iteration of independent deviations, within which the maximum element in a line is searched for, its ordinal number $p$ is remembered, and transition to the $p$-th line takes place followed by a new search for the maximum element of this line (Ivashkin, 2005).

To detect possible looping of cause-effect relationships, an array of indices of diagonal elements included in the interaction trajectory is formed, and when two elements of this array match, it is followed by a "cycle" signal. In this case, the cause may be inside or outside the cycle circuit. To exit the cause-effect cycle and continue to search for the original cause, the last link of feedback is broken, i.e. element $S_{g p}=0$, with its value $f_{g p}=S_{g p}$ and addresses memorized in index arrays $\operatorname{Ind}_{g_{1}}$; $\operatorname{Ind}_{g_{2}}$. Then when iterating over the elements of the $g$-th line, the procedure will either stop at the last link of the cycle (if the reason lies within the cycle circuit) or go further through the steps of a new cycle (Figure 2). When moving to the detection of the causal chain of the next $k+1$-th consequence, the interrupted link of the $j$-th cycle of the previous trajectory of the links is restored, i.e. $\mathrm{S}_{I n d_{j 1}, I_{d_{j 1}}}=f_{j}$.

To find the influence of other factors on the next $k$-th consequence, the first maximum contribution to its deviation is set equal to zero and the next largest element of the $k$-th line is selected, i.e. the next largest contribution to the $k$-th consequence.

All abnormal values of indicators are kept in the array of deviations from the norm, and based on the knowledge base, the person is provided with an initial selection of products for their recommended diet. The diet compensates for existing deviations and takes into account individual characteristics of the patient and social conditions (personal perception of certain product, presence of allergies, and availability of specific products due to material or geographical factors).

If there is insufficient compensation for deviations by selecting the desired products and dishes included in the diet, a search should be made for their optimal quantitative ratios (structural optimization) with the possible introduction of additional products and dishes, depending on the current deviations of parameters from the norms, or an individual combined product that minimizes residual deviations could be developed.

\section{Composed function of the dietary structure quality}

The quality and sufficiency of the dietary structure are determined, first of all, by its compliance with the requirements for the physiological characteristics of the body and the recommended norms for consumption of biochemical elements. To assess the sufficiency and quality of the daily ration, a composed function is proposed (Nikitina, 2020), reflecting the weighted average total deviation of the state parameters from actual to normative values. With regard to the weight coefficients and defining certain groups of factors, the quality functional looks like:

$$
F(x)=1-\sqrt{\frac{1}{n} \sum_{i=1}^{n} a_{i} \sum_{j=1}^{n_{i}} b_{i j}}\left(\frac{x_{i j}-x_{i j}^{0}}{\Delta x_{i j}^{k}}\right)
$$

where $n$ is the number of combined indicators;

$x_{i j}, x_{i j}^{0}$ are actual and required values;

$\Delta x_{i j}^{k}$ is maximum deviation from the required value for the $k$-th quality level;

$b_{i j}$ is weight coefficient of the $j$-th parameter in the $i$-th group;

$a_{i}$ is group significance factor.

The quality functional value range is presented in the form of the following graduated scale. If the quality functional value is equal to 1 , this means complete coincidence of food nutrients and energy with the recommended ones, i.e. the best quality is achieved. If the quality functional value is equal to 0 or takes negative values, the recommended values are not achieved, so the diet does not meet the specified quality level.

To determine weight coefficients, a complete factorial experiment can be used, where the following values are entered into columns of the response function of the $r$-th repetition in the $k$-th experiment: $1-0.7$ - when the product is classified as having a very good level of quality; $0.7-0.3$ - good; $0.3-0$ — satisfactory; 0 - $(-0.2)$ - bad; less than $(-0.2)$ very poor quality level.

\section{Information basis of the system}

The information basis of the system is a database with nine independent tables. These tables correspond to different types of dishes, namely: "zakuska" (snacks), "sladost" (desserts), "hleb" (baked goods), "napitok" (drinks), "kasha" (cereals), "salat" (salads and vinaigrettes), "sup" (first courses), "myasoriba" (main courses, meat and fish dishes), and "garner" (side dishes). 
Each table contains 15 fields. The Id field contains a simple index, which is used to retrieve the required record from the database. The "bludo" fields contain the names of various dishes the user can select from the drop-down list. Next are the fields with physicochemical indicators of dishes per 100 grams: "gir" (the field contains the fat content in the dish), "belki" (proteins), "uglevod" (carbohydrates), "cennost" (energy value of the dish), "C" (vitamin C), "B2" (vitamin B2), "B1" (vitamin B1), "PP" (vitamin $\mathrm{PP})$, "E" (vitamin E), "Ca" (calcium), "Fe" (iron), "P" (phosphorus), "Mg" (magnesium).

Each dish is given a specific record.

\section{Work within the system}

Working with a computer system can be represented as an aggregate block diagram (Figure 3). At the first stage, based on anthropometric data and biomarkers (hemogram, acidity of gastrointestinal tract) of the person's physiological state, a user model ("a human health passport") is generated in the system. The model considers the risk of disease and the gastrointestinal tract status. The model description includes such descriptors as individual nutritional needs, biomedical requirements, dietary habits, and available allergies.

At the second stage, the system allows one to make a choice of products considering the person's

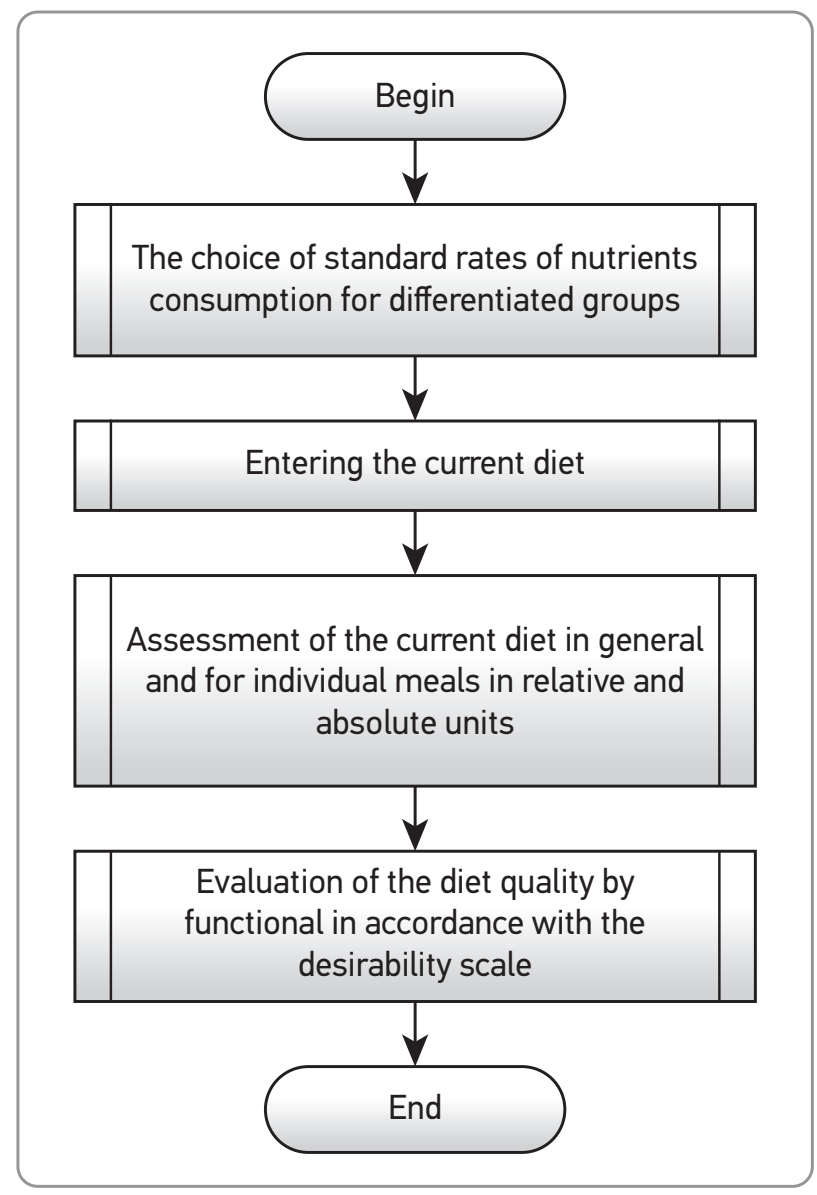

Figure 3. An aggregate block diagram of a healthy diet based upon a person's "health passport"

\begin{tabular}{|c|c|c|c|c|c|c|c|c|c|c|c|c|c|c|}
\hline \multicolumn{15}{|c|}{ Breakfast } \\
\hline & Yield, $g$ & $\begin{array}{c}\text { Proteins } \\
\text { g. }\end{array}$ & Fat, $\mathbf{g}$. & $\begin{array}{c}\text { Carbo- } \\
\text { hydrates, } 9 .\end{array}$ & \begin{tabular}{|c|} 
Energy \\
value, kcal
\end{tabular} & $\mathrm{C}, \mathrm{mg}$ & $\begin{array}{l}\mathrm{B} 2 \\
\mathrm{mg}\end{array}$ & $\begin{array}{l}\text { B1, } \\
\text { mg. }\end{array}$ & $\begin{array}{l}\mathrm{PP}, \\
\mathrm{mg} \text {. }\end{array}$ & $\begin{array}{c}\mathrm{E}_{1} \\
\mathrm{mg}\end{array}$ & $\begin{array}{l}\mathrm{CA} \text {, } \\
\mathrm{mg} .\end{array}$ & $\begin{array}{l}\mathrm{Fe} \text {, } \\
\mathrm{mg} .\end{array}$ & P, mg. & $\begin{array}{l}\mathrm{Mg} \text {, } \\
\mathrm{mg}\end{array}$ \\
\hline Boiled egg & 70 & 8.05 & 8.925 & 0.525 & 110.25 & 0.14 & 0.315 & 0.126 & 0.35 & 1.05 & 38.5 & 1.351 & 336 & 21 \\
\hline $\begin{array}{l}\text { 'Magdalena' } \\
\text { cake }\end{array}$ & 60 & 3.27 & 14.346 & 31.452 & 236.184 & 21.27 & 0.456 & 0 & 0 & 0 & 0 & 0 & 0 & 0 \\
\hline $\begin{array}{l}\text { Doctor's } \\
\text { crisploread }\end{array}$ & 60 & 1.56 & 4.92 & 27.78 & 145.2 & 0 & 0.03 & 0.096 & 1.98 & 1.02 & 10.2 & 0.84 & 51.6 & 21.6 \\
\hline $\begin{array}{l}\text { Plain black } \\
\text { coffee }\end{array}$ & 200 & 0.1 & 0.4 & 0.4 & 14 & 0 & 0 & 0 & 1.2 & 0 & 10 & 0 & 14 & 0 \\
\hline $\begin{array}{l}\text { "Health" } \\
\text { Muesli Pear } \\
\text { (25\% of nuts } \\
\text { and fruits) }\end{array}$ & 50 & 4.3 & 1.75 & 32 & 133 & 28.515 & 0.055 & 0.12 & 0 & 0.3 & 33 & 0 & 0 & 45 \\
\hline $\begin{array}{l}\text { Total for } \\
\text { breakfast }\end{array}$ & & 17.28 & 30.341 & 92.157 & 638.634 & 49.925 & 0.856 & 0.342 & 3.53 & 2.37 & 91.7 & 2.191 & 401.6 & 87.6 \\
\hline \multirow{2}{*}{$\begin{array}{l}\text { As a percentage } \\
\text { of the } \\
\text { recommended } \\
\text { daily ration }\end{array}$} & \begin{tabular}{|l} 
Young \\
men
\end{tabular} & 15.29 & 29.46 & 20.43 & 19.35 & 62.41 & 42.8 & 21.38 & 17.65 & 23.7 & 11.46 & 21.91 & 33.47 & 21.9 \\
\hline & Girls & 18 & 33.71 & 24.06 & 22.81 & 62.41 & 57.07 & 26.31 & 19.61 & 29.63 & 11.46 & 12.17 & 40.16 & 21.9 \\
\hline
\end{tabular}

Figure 4. Estimated indicators of food nutrients for "Breakfast" 
physiological state. For example, if a person has celiac disease, then products, dishes and culinary products containing gluten are automatically excluded from their menu.

At the third stage, the developed diet is assessed, and the food nutrients (proteins, fats, carbohydrates, vitamins, macro- and microelements) in the diet are analyzed and compared with the recommended norms for this particular person (Figure 4). The assessment is carried out for individual meals (breakfast, lunch, dinner) and for the whole diet during the day in absolute and relative units.

As we can see in Figure 4, the first column displays the names of selected dishes, culinary and food products; the second column indicates the weight of the serving. This is the data the user enters at the second stage, when they make up their diet based on their preferences. The remaining columns display physical and chemical indicators cal culated by the system. All indicators are presented at three levels.

- The first level: calculation of indicators for each dish, culinary product and food product separately;

- The second level: calculation of complex indicators for breakfast, lunch and dinner in general;

- The third level: calculation of daily outcome indicators.
In addition to summarizing the overall results (Figure 4), the system compares the indicators with the recommended daily rates as a percentage.

At the fourth stage, the composed function of quality is calculated. If the obtained value of the quality functional corresponds to the acceptable level of the desirability scale, then the user receives their daily ration with differentiation in time and recommendations for food intake. Otherwise, if the diet does not meet their physiological needs, then a return to the second stage to adjust the diet is made. At that stage, products can be replaced if desired.

\section{Conclusion}

The developed computer system based on mathematical models provides a solution for the problem of structural-parametric diet optimization, adjusted for a variety of constraints and conditions, and produces the optimum solution for the given utility functions. It 1) is easy to use, allowing the daily diet to be assessed quickly and reliably, and; 2) establishes whether any imbalance (excess/deficiency) of nutrients exists in the diet. The knowledge available in the system builds a cause-and-effect relation for the statement "If there is a shortage or excess of this or that food nutrient in the body, then this will lead to such and such a disease." Dietary structure (diet) is a health factor that can be changed easily to improve one's health.

\title{
Digitalna rešenja za zdravu ishranu
}

\author{
Marina A. Nikitina, Irina M. Chernukha, Andrej B. Lisitsyn
}

A p s t r a k $t$ : U ovom istraživanju predstavljen je kompjuterski sistem koji se koristi za procenu zdrave ishrane. Na osnovu matematičkih modela, sistem daje rešenje za problem strukturno-parametarske optimizacije ishrane, prilagođene različitim ograničenjima i uslovima, i proizvodi optimalno rešenje za date funkcije korisnosti. Informaciona osnova sistema je baza podataka koja sadrži devet nezavisnih tabela. Svaka tabela sadrži 15 polja. Koristi se jezik strukturiranih upita (structured query language SQL). Opisan je agregatni algoritam za implementaciju rešenja sastava zdrave ishrane, koji sadrži četiri etape, uz dužno razmatranje , ljudskog zdravstvenog pasoša". U prvoj fazi, na osnovu antropometrijskih podataka i biomarkera (hemogram, kiselost gastrointestinalnog trakta) fiziološkog stanja osobe, sistem generiše korisnički model (, ljudski zdravstveni pasoš“). Model uzima u obzir rizik od bolesti i status gastrointestinalnog trakta. U drugoj fazi, sistem omogućava izbor prehrambenih proizvoda na osnovu fiziološkog stanja osobe, $i$ koji proaktivno isključuje nepoželjne prehrambene proizvode, jela i kulinarske proizvode. U trećoj fazi procenjuje se razvijena ishrana $i$ analiziraju hranljive materije (proteini, masti, ugljeni hidrati, vitamini, makro i mikroelementi) u ishrani i upoređuju sa preporučenim normama za ovu osobu. U četvrtoj fazi, adekvatnost ishrane se procenjuje prema funkciji kvaliteta.

Ključne reči: kompujterski sistem, zdravlje, ishrana.

Disclosure statement: No potential conflict of interest was reported by authors.

Acknowledgments: This article is published as part of scientific research theme No. 0585-2019-008 under the state assignment of the federal state budgetary scientific institution V.M. Gorbatov's Federal Research Centre for Food Systems of RAS. 


\section{References}

Alpaslan, F. 1996. Türkiye'de 6 Büyük İlde Doğrusal Programlama ile Optimum Beslenme Maliyetinin Minimizasyonu (1994-1997) Ondokuz Mayls University, Fen-Edebiyat Fakültesi Araştırma Fonu F 150, 6-8.

Anderson, A. M and Earle, M. D. 1983. Diet Planning in the Third World by Linear and Goal Programming. Journal of the Operation Research Society, 34, 9-16.

Bush, C. L., Blumberg, J. B., El-Sohemy, A., Minich, D. M., Ordovas, J. M., Reed, D. G \& Behm, V. A. Y. 2020. Toward the definition of personalized nutrition: A proposal by the American nutrition association. Journal of American College Nutrition 39 (1), 5-15.

Chen, C-H, Karvela, M., Sohbati, M., Shinawatra, T and Toumazou, C. 2018. Person - personalized expert recommendation system for optimized nutrition. IEEE Transactions on Biomedical Circuits System, 12 (1), 151-60.

Davis-Dusenbery, B. 2017. Precision Medicine and Big Data. Pharmaceutical Executive, 37 (3), 14.

Division of Nutrition, Physical Activity, and Obesity (https:// www.cdc.gov/vitalsigns/adultobesity/infographic.html)

Edwardson, W. 1974. The Design of Nutritional Food Products for a Developing Country (Massey: Massey University).

Ivashkin, Yu, A., Yudina, S. B., Nikitina, M. A \& Azarova, N. G. 2000. Information technologies for food design Meat Industry, 5 40-1.

Ivashkin, Yu. A. 2005. System Analysis and Operations Research in Applied Biotechnology (Moscow: Moscow State University of Applied Biotechnology).

Kaldırım, E \& Köse, Z. 2006. Application of a Multiobjective Genetic Algorithm to the Modified Diet Problem Genetic and Evolutionary Computation Congress (USA: Seattle).

Lipatov, N. N. 1985. Methods for quantifying and modelling the amino acid balance of meat products The $31^{\text {st }}$ European congress of meat scientists 158-61.

Lisitsyn, A., Chernukha, I. \& Nikitina, M. 2020. Russian methodology for designing multicomponent foods in retrospect. Foods Raw Material, 8 (1), 2-11.
Lv, Y 2009. Multi-objective nutritional diet optimization based on quantum genetic algorithm Procceedings ICNC, 4, 336-40.

Musina, O. N \& Lisin, P. A. 2015. An approach to the choice of alternatives of the optimized formulations. Foods Raw Material, 3 (2), 65-73.

Musina, O., Putnik, P., Koubaa, M., Barba, F. J., Greiner, R., Granato, D \& Roohinejad, S. 2017. Application of modern computer algebra systems in food formulations and development: A case study. Trends in Food Science and Technology, 64, 48-59.

Nikitina, M. A. 2020. Structural-parametric modeling in human healthy nutrition system. CEUR Workshop Proceedings, 2667, 219-24.

Nikitina, M. A., Chernukha, I. M \& Nurmukhanbetova, D. E. 2019. Principal approaches to design and optimization of a diet for targeted consumer groups News of the National Academy of Sciences of the Republic of Kazakhstan. Series of Geology and Engineering, 433 (1), 231-41.

Prosekov, A. Yu. 2020. The methodology of food design. Part 1. The individual aspect. Theory and Practice of Meat Processing, 5 (4), 13-17.

Sahingoz, S. A \& Sanlier, N. 2011. Compliance with Mediterranean Diet Quality Index (KIDMED) and nutrition knowledge levels in adolescents. A case study from Turkey $\mathrm{Ap}$ petite, 57 (1), 272-7.

Sukhatme, P. V. 1961. The World's Hunger and Future Needs in Food Supplies. Journal of Royal Statical Society, 124, 463-525.

The Merck Manual of Medical Information Whitehouse Station, 2008. (St. Petersburg: Norint).

Wu, P. Y., Cheng, C. W., Kaddi, C. D., Venugopalan, J., Hoffman, R \& Wang, M. D. 2017. Omic and electronic health record big data analytics for precision medicine IEEE Transaction on Biomedical Engineering, 2, 263-73.

Youbo, Lv, 2009. Multi-objective nutritional diet optimization based on quantum genetic algorithm. Fifth International Conference on Natural Computation, 336-40. 